\title{
SPECTROPHOTOMETRIC AND SPECTROFLUORIMETRIC DETERMINATION OF SOME DRUGS CONTAINING SECONDARY AMINO GROUP IN BULK DRUG AND DOSAGE FORMS VIA DERIVATIZATION WITH 7-CHLORO-4-NITROBENZOFURAZON
}

\author{
Armağan Önal \\ Department of Analytical Chemistry, Faculty of Pharmacy, Istanbul University, 34116, Beyazit, Istanbul - Turkey
}

Recebido em 9/3/10; aceito em 22/9/10; publicado na web em 31/1/11

\begin{abstract}
Sensitive and selective spectrophotometric and spectrofluorimetric methods have been developed for determination of some drugs such as Pramipexole, Nebivolol, Carvedilol, and Eletriptan, which commonly contain secondary amino group. The subject methods were developed via derivatization of the secondary amino groups with 7-Chloro-4-Nitrobenzofurazon in borate buffer where a yellow colored reaction product was obtained and measured spectrophotometrically or spectrofluorimetrically. Concentration ranges were found as 2.0 to $250 \mu \mathrm{g} \mathrm{mL}-1$ and 0.1 to $3.0 \mu \mathrm{g} \mathrm{mL}^{-1}$, for spectrophotometric and spectrofluorimetric study, respectively. The described methods can be easily applied by the quality control laboratories in routine analyses of these drugs in pharmaceutical preparations.
\end{abstract}

Keywords: secondary amino groups; 7-chloro-4-nitrobenzofurazan; pharmaceutical preparations.

\section{INTRODUCTION}

Pramipexole ((6S)- $N^{6}$-propyl-4,5,6,7-tetrahydro-1,3-benzothiazole-2,6-diamine, PRM) is a non-ergoline dopamine agonist, initially introduced for the treatment of early and advanced Parkinson's disea$\mathrm{se}^{1}$ and recently approved in US and Europe also for the treatment of idiopathic restless legs syndrome in adults. ${ }^{2}$ Nebivolol hydrochloride (NBV) is chemically known as $\alpha, \alpha^{\prime}$-[iminobis(methylene)]bis[6flouro-3,4-dihydro-2H-1-benzopyran-2-methanol]hydro-chloride, ${ }^{3}$ it is a highly selective $\beta_{1}$-blocker with nitric oxide-mediated vasodilatory actions and beneficial effects on vascular endothelial function. It is a third-generation, cardio-selective beta-blocker used for the treatment of hypertension and chronic heart failure. ${ }^{4}$ Carvedilol (CRV), 1-(carbazol-4-yloxy)- 3-((2methoxyphenoxy)ethyl)amino)-2propanol (Figure 1), is a non-selective beta adrenergic blocking agent. ${ }^{5}$ Eletriptan (ETP), [(R)-3-(1-methyl-2-pyrrolidinylmethyl)-5[2-(phenylsulphonyl)-ethyl]-1H-indole] (Figure 1), which is a new serotonin 5-HT(1B/1D) receptor agonist, has been developed for the treatment of acute migraine attacks. ${ }^{6}$ Chemical structures of the subject APIs were given in Figure 1.

There are only a limited number of analytical methods developed for analysis of these drugs in dosage forms. Previously, analysis of Pramipexole in bulk and drug products was carried out by a high performance liquid chromatographic (HPLC) method. ${ }^{7,8}$ Five HPLC ${ }^{9}$ ${ }^{13}$ and densitometric ${ }^{14}$ methods have been reported for determination of NBV in drug products. Two spectrophotometric methods were reported for the determination of CRV. ${ }^{15,16}$ The literature data for ETP indicates only one HPLC method utilized in analysis of Eletriptan in dosage forms. ${ }^{17}$

Although chromatographic methods are sensitive and accurate, their major disadvantages comprise utilization of complex and expensive equipment, usage and disposal of high purity solvents, application of labor-intensive sample preparation procedures as well as longer duration of analyses. In view of that, new spectrophotometric/ spectrofluorometric methods were developed via derivatization of the

*e-mail: armaganozkul@yahoo.com<smiles>CCCNC1CCC2N=C(N)SC2C1</smiles><smiles>CCCCCC(O)C(O)CNCC(O)C1CCc2cc(F)ccc2O1</smiles>

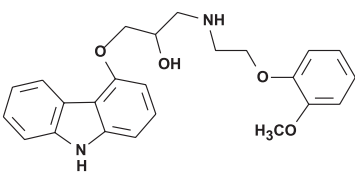

CRV

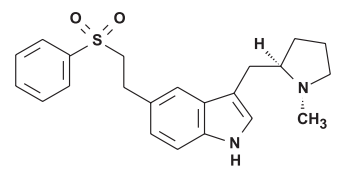

ELT
Figure 1. Chemical structures of drugs, (A) Pramipexole, (B) Nebivolol, (C) Carvedilol, (D) Eletriptan

secondary amino group of the subject drugs with 7-Chloro-4-Nitrobenzofurazon (NBD-Cl), which is well known to react with primary and secondary amines forming stable condensation colored products. ${ }^{18}$ The condensation products of NBD-Cl have been demonstrated to be suitable for spectrophotometric and spectrofluorimetric assessments therefore, it has been used in analyses of many pharmaceutical formulations or biological fluids. ${ }^{19-23}$ The developed methods were also validated successfully for specificity, linearity, accuracy, precision, robustness and they have been applied for quantification of these drugs in tablets, avoiding interferences caused by the excipients. The proposed methods can be easily used in laboratories where modern and expensive apparatus are not available.

\section{EXPERIMENTAL}

\section{Apparatus}

Spectrophotometric measurements were carried out using a Shimadzu UV-160 A spectrophotometer and 1-cm glass cells. Fluorescence spectra and measurements were taken on a Shimadzu spectrofluorimeter Model RF-1501 equipped with xenon lamp and 1-cm quartz cells. $\mathrm{pH}$ measurements were made with WTW pH 526 digital pH Meter. 


\section{Reagents and solutions}

Pramipexole Hydrochloride and Nebivolol Hydrochloride drug substances and its pharmaceutical preparation ( $\mathrm{Nexivol}^{\circledR}$ containing $5 \mathrm{mg} /$ tablet Nebivolol Hydrochloride) were kindly supplied by Abdi Ibrahim Pharmaceuticals (Istanbul, Turkey). Pexola ${ }^{\circledR}$ containing $1 \mathrm{mg}$ of pramipexole hydrochloride per tablets was obtained from local drugstore. Carvedilol and its pharmaceutical preparation (Kinetra ${ }^{\circledR}$ ) containing $25 \mathrm{mg}$ of Carvedilol per tablet were procured from Sanovel (Istanbul, Turkey). Eletriptan Hydrobromide and its pharmaceutical preparation (Relpax film coated tablet ${ }^{\circledR}$ ) containing $40 \mathrm{mg}$ of Eletriptan Hydrobromide per tablet were kindly supplied by Pfizer (Istanbul, Turkey). NBD-Cl and other chemicals were purchased from Merck (Darmstadt, Germany). All chemicals and reagents were of analytical-reagent grade. A stock solution of PRM base containing $1 \mathrm{mg} \mathrm{mL}^{-1}$ was prepared in water. A stock solution of $\mathrm{NBV}$ base containing $10 \mathrm{mg} \mathrm{mL}^{-1}$ was prepared in methanol. A stock solution of CRV (1 $\left.\mathrm{mg} \mathrm{mL}^{-1}\right)$ was prepared in acetonitrile. ETP stock solution $1.0 \mathrm{mg} / \mathrm{mL}$, calculated as free base was prepared in methanol.

NBD-Cl solution was freshly prepared in methanol at $5 \mathrm{mg} \mathrm{mL}^{-1}$ concentration. Buffer solution was prepared as follow: $0.620 \mathrm{~g}$ boric acid and $0.750 \mathrm{~g}$ potassium chloride were dissolved with $100 \mathrm{~mL}$ of water. After adjusting the $\mathrm{pH}$ to 8.0 and 8.5 with $0.1 \mathrm{~N}$ sodium hydroxide solution, the final solution was diluted to $200 \mathrm{~mL}$ with water.

\section{General procedure}

\section{Pramipexole}

This material was analyzed using both spectrophotometric and spectrofluorimetric methodology. Aliquots of the stock standard solution varied from $0.05-0.3$ and $0.015-0.15 \mathrm{~mL}$, for the spectrophotometric and spectrofluorimetric studies, respectively, were transferred into a series of $10.0 \mathrm{~mL}$ volumetric flasks and then the volume was adjusted to about 0.3 and $0.15 \mathrm{~mL}$ with water, for spectrophotometric and spectrofluorimetric study, respectively.

\section{Nebivolol}

Aliquot of the associated stock standard solution ranged between 0.005 and $0.060 \mathrm{~mL}$ were transferred into a series of $10.0 \mathrm{~mL}$ volumetric flasks and then the volume was adjusted to about 0.060 $\mathrm{mL}$ with methanol.

\section{Carvedilol}

Aliquots of its stock standard solution between 0.035 and 0.300 $\mathrm{mL}$ were individually transferred into glass stoppered tubes and their volumes were brought to $0.300 \mathrm{~mL}$ with acetonitrile.

\section{Eletriptan}

Aliquots of its stock standard solution $(0.15-1.25 \mathrm{~mL})$ were individually transferred into glass stoppered tubes and their final volumes were brought to $1.25 \mathrm{~mL}$ with methanol. Following addition of 0.2 $\mathrm{mL}$ of buffer solution to each drug solutions, $0.7,0.8,0.3$ and 0.5 $\mathrm{mL}$ of NBD-Cl solutions were added to PMP, NBV, CRV and ELT, respectively and the mixtures treated in water bath with thermostat at $70{ }^{\circ} \mathrm{C}$ for $30 \mathrm{~min}$ for $\mathrm{NBV}$ and $80{ }^{\circ} \mathrm{C}$ for 7,20 and $30 \mathrm{~min}$ for PMP, CRV and ELT, respectively. The mixtures were then cooled within a ice bath and acidified with $0.2 \mathrm{~mL}$ of $0.1 \mathrm{M} \mathrm{HCl}$ solution. The derivatives of individual drug substances formed by coupling with NBD-Cl, were extracted using $5 \mathrm{~mL}$ aliquots of chloroform (for PRM and CRV), dichloromethane (for NBV) and ethyl acetate (for ELT) by mixing vigorously with a vortex mixer. The phases were separated by centrifugation. For the spectrophotometric studies, absorbance values of the derivatives extracted to the organic layers were measured at their respective maximum wavelengths against a blank solution prepared similarly.

For the spectrofluorimetric studies, upon completion of the extraction process, $1 \mathrm{~mL}$ aliquots of the organic phase were transferred to $10 \mathrm{~mL}$ volumetric flasks and their volumes were diluted to 10 $\mathrm{mL}$ with chloroform (for PRM) or dichloromethane (for NBV) and mixed well. The fluorescence intensities of these derivatives were measured at 529 and $530 \mathrm{~nm}$ (for PRM and NBV) while exciting at 470 and $473 \mathrm{~nm}$ (for PRM and NBV) measured against blank solutions prepared similarly. The fluorescence intensity of the reference standard, sodium fluoressein, solution was also measured at the same wavelength combination. The relative fluorescence intensity $\left(I_{\mathrm{F}}\right)$ was then calculated by the following equation: $I_{\mathrm{F}}=x / y \times 100 . x$ and $y$ represent the fluorescence intensities of the sample and reference standard solutions, respectively $(n=5)$.

\section{Assay procedure for tablets}

\section{Pramipexole}

Tablet powder equivalent to $50 \mathrm{mg}$ of PRM base was accurately weighed and transferred into a $50 \mathrm{~mL}$ calibrated volumetric flask. About $25 \mathrm{~mL}$ of water was added and then extraction was performed by shaking mechanically for $20 \mathrm{~min}$ and sonicating for 20 more min. Upon completion of the extraction step, the volume of the mixture was brought to $50 \mathrm{~mL}$ with water and mixed well by vortexing. Then, final solution was filtered through a 0.45 um nylon filter.

\section{Nebivolol}

Tablet powder equivalent to $50 \mathrm{mg}$ of NBV base was accurately weighed and transferred into a $50 \mathrm{~mL}$ calibrated flask. About $25 \mathrm{~mL}$ of methanol was added and then extraction was performed mechanically for $20 \mathrm{~min}$ and sonicated for 20 more min. The volume was brought to $50 \mathrm{~mL}$ with methanol and final solution was filtered.

\section{Carvedilol}

Ten tablets were individually weighed to get the average weight of the tablets. A sample of the powdered tablets, claimed to contain $100 \mathrm{mg}$ of CRV was transferred to $100 \mathrm{~mL}$ volumetric flask. About $75.0 \mathrm{~mL}$ of acetonitrile was added and then extraction was performed mechanically for $20 \mathrm{~min}$ and sonicated for 20 more min. The volume was brought to $100 \mathrm{~mL}$ with acetonitrile and its contents were centrifuged for $10 \mathrm{~min}$ at $3000 \times g$.

\section{Eletriptan}

Ten film-coated tablets were transferred to $500 \mathrm{~mL}$ volumetric flask. About $400 \mathrm{~mL}$ of methanol was added and then extraction was performed mechanically for $20 \mathrm{~min}$ and sonicated for 20 more min. The volume was brought to $500 \mathrm{~mL}$ with methanol and final solution was filtered. Then $1 \mathrm{~mL}$ of this solution was further diluted to 100 mL using methanol.

Aliquots of the filtrates were further diluted with solvents stated above then proceeded with the solution preparation scheme as described under of the general procedure section. The nominal contents of the tablets were calculated using either the calibration graph or the corresponding regression equation.

\section{RESULTS AND DISCUSSION}

NBD-Cl was selected as a derivatizing reagent because it forms fluorescent/chromogenic derivatives with primary or secondary amines requiring relatively mild reaction conditions. ${ }^{19-23} \mathrm{PRM}, \mathrm{NBV}$, CRV and ELT contain secondary amino group which is known to react with NBD-Cl in alkaline medium (Figure 2). The absorbance of 
the generated derivatives were then measured at their respective $\lambda_{\max }$ which were outlined in Table 1. Figure 3 shows absorption spectra of drug-NBD derivatives against the blank prepared similarly.

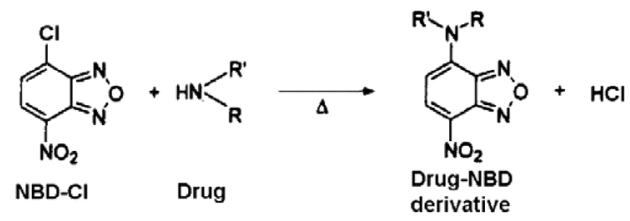

Figure 2. Proposed reaction pathway between drug containing secondary amine and $\mathrm{NBD}-\mathrm{Cl}$

Under the developed experimental conditions, the maximum fluorescence intensities for PRM and NBV were determined at 529 and $530 \mathrm{~nm}$ while excitation took place at 470 and $473 \mathrm{~nm}$, respectively. Figure 4 shows the excitation and emission spectra for PRM-NBD and NBV-NBD derivatives. When NBD derivatives of CRV and ELT were measured against a blank prepared using a spectrofluorimetry, no substantial differences have been determined. Therefore, NBD derivatives of CRV and ELT were studied utilizing spectrophotometric methods.

\section{Study of experimental parameters}

The different experimental parameters affecting the development of the reaction product were carefully studied and optimized. The variability/optimization of the main reaction parameters such as $\mathrm{pH}$, volume of the reagent, temperature, and heating time were studied individually.

\section{Effect of $\mathrm{pH}$ and $\mathrm{HCl}$ concentration}

The $\mathrm{pH}$ study was completed within the range of 7-10 using borate buffers. The maximum absorbance was obtained at $\mathrm{pH} 8.5$ for PRM and NBV and at pH 8 for ELT and CRV. The test results for $\mathrm{pH}$ studies are summarized in Figure 5.

NBD-Cl is hydrolyzed in alkaline medium by formation of NBD$\mathrm{OH}$ having a maximum absorbance at $460 \mathrm{~nm}$. In order to decrease high background effect, it was necessary to acidify the reaction mixture. The required amount of $\mathrm{HCl}$ for acidification was determined as $0.2 \mathrm{~mL}$ of $0.1 \mathrm{M} \mathrm{HCl}$.

\section{Effect of temperature and time}

In order to determine the optimum temperature and time required for the completion of the reaction, the derivatization reaction was carried between the range of 60 to $80^{\circ} \mathrm{C}$. Complete color development was attained after 7, 20 and $30 \mathrm{~min}$ for PMP, CRV and ELT, respectively in water bath at $80^{\circ} \mathrm{C}$ while heating at $70{ }^{\circ} \mathrm{C}$ for $30 \mathrm{~min}$ was sufficient to fulfill the optimum reaction requirement for $\mathrm{NBV}$ (Figure 6).
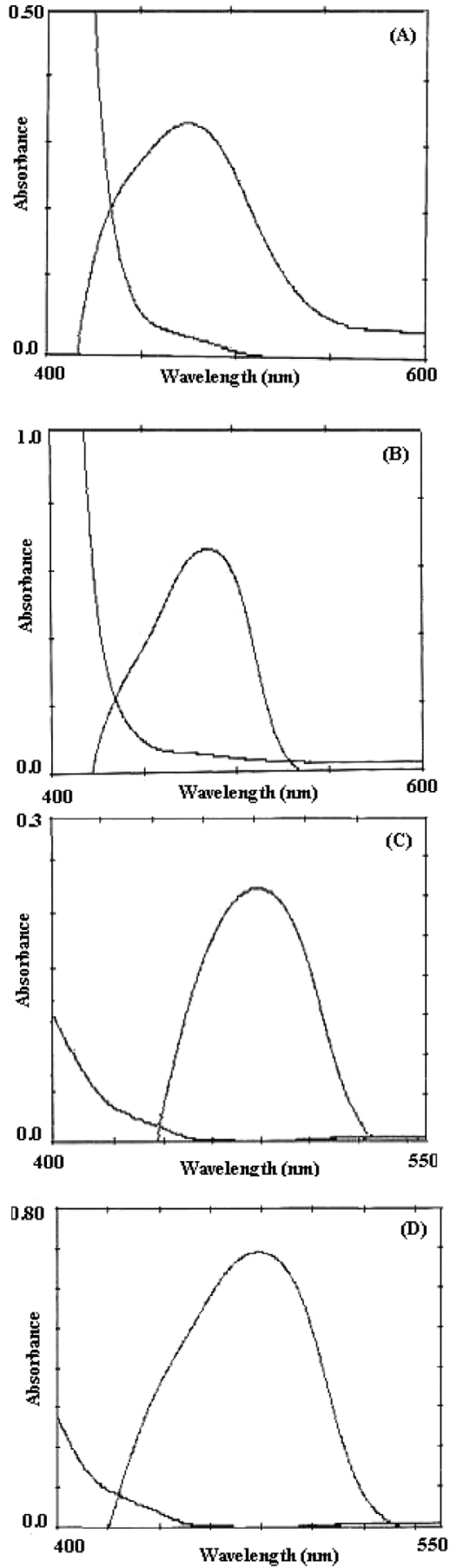

Figure 3. Absorption spectra of drug-NBD derivative against reagent blank (A) Pramipexole, (B) Nebivolol, (C) Carvedilol, (D) Eletriptan

Table 1. Optimization of variables affecting the reaction of drugs with NBD-Cl

\begin{tabular}{|c|c|c|c|c|}
\hline \multirow[t]{2}{*}{ Variable } & \multicolumn{4}{|c|}{ Optimum condition } \\
\hline & For PRM-NBD & For NBV-NBD & For CRV-NBD & For ELT-NBD \\
\hline $\mathrm{pH}$ & 8.5 & 8.5 & 8.0 & 8.0 \\
\hline $\mathrm{HCl}(\mathrm{M}), \mathrm{mL}$ & $0.1 \mathrm{M}, 0.2 \mathrm{~mL}$ & $0.1 \mathrm{M}, 0.2 \mathrm{~mL}$ & $0.1 \mathrm{M}, 0.2 \mathrm{~mL}$ & $0.1 \mathrm{M}, 0.2 \mathrm{~mL}$ \\
\hline Temperature $\left({ }^{\circ} \mathrm{C}\right)$ & 80 & 70 & 80 & 80 \\
\hline Time (min) & 7 & 30 & 20 & 30 \\
\hline $\begin{array}{c}\mathrm{NBD}-\mathrm{Cl}(\%, \mathrm{w} / \mathrm{v}) \text { and } \mathrm{mL} \\
\text { Solvent }\end{array}$ & $\begin{array}{c}0.5(\%, \mathrm{w} / \mathrm{v}) \text { and } 0.7 \mathrm{~mL} \\
\text { chloroform }\end{array}$ & $\begin{array}{c}0.5(\%, \mathrm{w} / \mathrm{v}) \text { and } 0.8 \mathrm{~mL} \\
\text { dichloromethane }\end{array}$ & $\begin{array}{c}0.5(\%, \mathrm{w} / \mathrm{v}) \text { and } 0.3 \mathrm{~mL} \\
\text { chloroform }\end{array}$ & $\begin{array}{c}0.5(\%, \mathrm{w} / \mathrm{v}) \text { and } 0.5 \mathrm{~mL} \\
\text { ethyl acetate }\end{array}$ \\
\hline
\end{tabular}



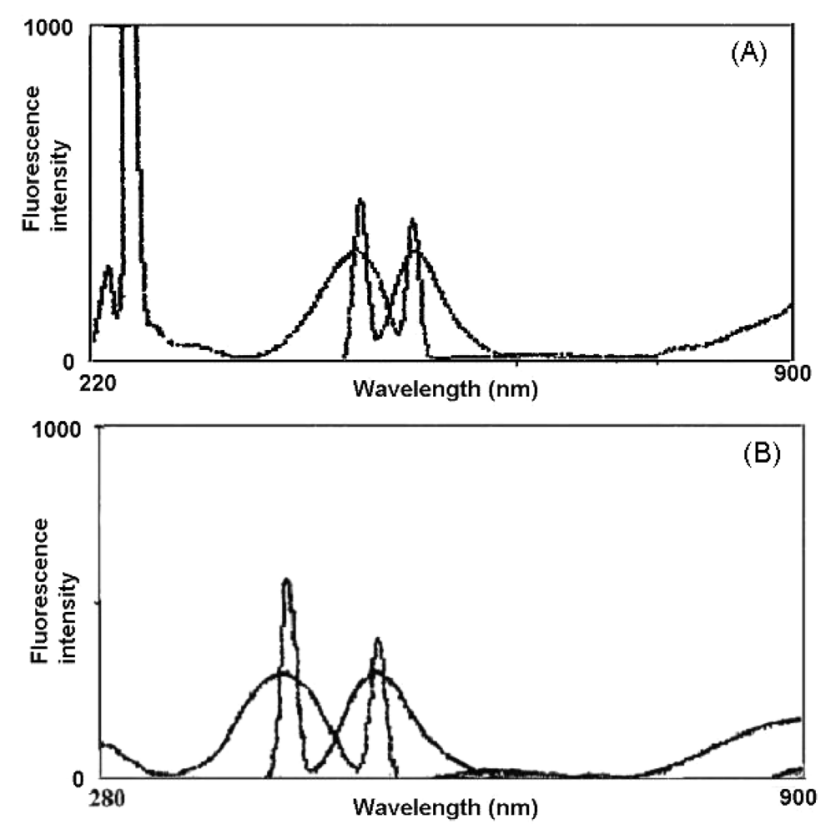

Figure 4. Excitation and emission spectra of the reaction product of drugs with NBD-Cl (A) Pramipexole, (B) Nebivolol

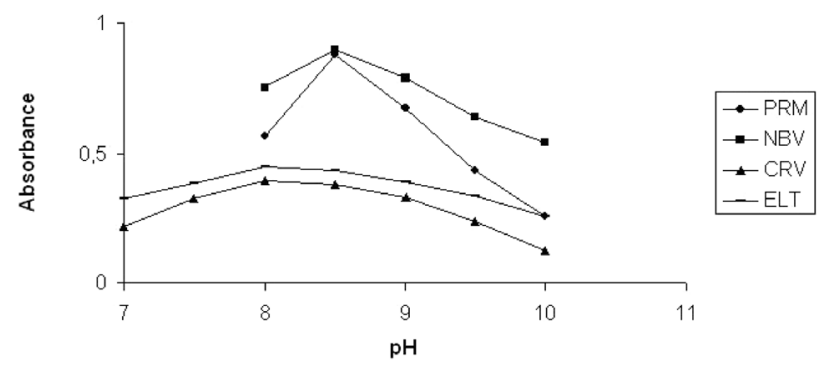

Figure 5. Effect of $\mathrm{pH}$ on the development of the reaction product of drugs with $\mathrm{NBD}-\mathrm{Cl}$

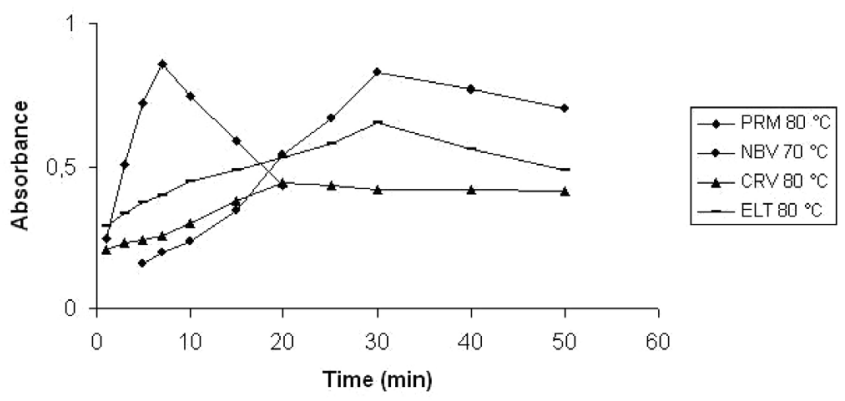

Figure 6. The effect of time of heating on the reaction between drugs with $\mathrm{NBD}$-Cl at optimum temperature

\section{Effect of NBD-Cl concentration}

The concentration range of $\mathrm{NBD}-\mathrm{Cl}$ was also investigated. Additions of $0.7,0.8,0.3$ and $0.5 \mathrm{~mL}$ of $0.5 \% \mathrm{NBD}-\mathrm{Cl}$ solution were found to be sufficient for obtaining maximum and reproducible color intensity for PMP, NBV, CRV and ELT, respectively. Refer to Figure 7 for the summarized related data points.

Effect of organic solvents and stability of the derivative

Different organic solvents were tested to determine the most appropriate solvent: methanol, ethyl acetate, dichloromethane, chloroform and acetonitrile. Chloroform (for PRM and CRV), dichloromethane (for NBV) and ethyl acetate (for ELT) were found to

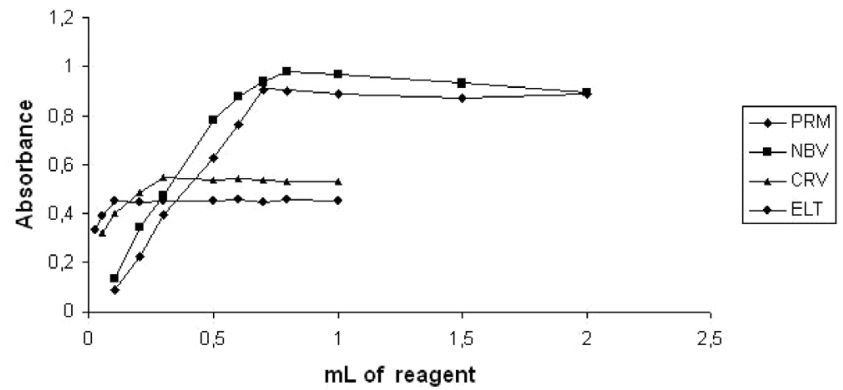

Figure 7. Effect of volume of $\mathrm{NBD}-\mathrm{Cl}(0.5 \%, w / v)$ on the development of the reaction product of drug with $\mathrm{NBD}-\mathrm{Cl}$

be the suitable solvents providing the highest absorbance values. The effect of time on the stability of the drug-NBD derivative in organic solvents was studied at different time intervals. The color remains stable at least for $12 \mathrm{~h}$.

A summary for the optimization of the variables affecting the reaction of these drugs with $\mathrm{NBD}-\mathrm{Cl}$ are given in Table 1.

\section{Stoichiometry of the reaction}

The molar ratio of NBD-Cl and the subject API in the reaction mixture was studied according to Job's method of continuous variation. ${ }^{24}$ Utilizing equimolar solution of drugs and NBD-Cl, the reaction stoichiometry was found to be a good approximation 1:1 ratio (drug/reagent).

\section{Validation of the methods}

A linear correlation was established between the absorbance and concentration values in the ranges as outlined in Table 2. The correlation coefficients, intercepts and slopes for the calibration data for the four cited APIs are calculated using the least squares method. These values are illustrated in Table 2. Under the optimum reaction conditions relative fluorescence intensity was found to be linearly correlated with the API concentration over the range of 0.3-3.0 $\mu \mathrm{g}$ $\mathrm{mL}^{-1}$ for PRM and $0.10-1.2 \mu \mathrm{g} \mathrm{mL} \mathrm{m}^{-1}$ for NBV. Linear regression analysis of the concentration-fluorescence intensity data gave the following equation: $I_{\mathrm{f}}=22.181 C+8.0837$ for PRM and $I_{\mathrm{f}}=722.1 C$ +152.69 for NBV where $C$ is the concentration in $\mu \mathrm{g} \mathrm{mL} L^{-1}$ and $I_{\mathrm{f}}$ is the fluorescence intensities $(n=5)$. The correlation coefficient was 0.9983 and 0.9999 for PRM and NBV methods showing excellent linearity. The limit of detection (LOD) and limit of quantitation (LOQ) were determined using the formula: $\mathrm{LOD}$ or $\mathrm{LOQ}=\kappa \mathrm{SDa} / \mathrm{b}$, where $\kappa=3$ for LOD and 10 for LOQ, SDa is the standard deviation of the intercept, and $b$ is the slope. The parameters for the analytical performance of the proposed methods are summarized in Table 2.

To check accuracy of the proposed methods, the standard addition technique was applied. Aliquots of the sample solution was spiked with three different concentrations of the standard solution. The percent recoveries of the added standards were calculated using the Equation 1.

$$
\text { Recovery } \%=\left[\left(\mathrm{C}_{\mathrm{t}}-\mathrm{C}_{\mathrm{u}}\right) / \mathrm{C}_{\mathrm{a}}\right] \times 100
$$

where $C_{t}$ is the total concentration of the analyte found; $C_{u}$ is the concentration of the analyte present in the formulation; and $\mathrm{C}_{\mathrm{a}}$ is the concentration of the pure analyte added to the formulation. The results of analysis of the commercial dosage forms and the recovery study are shown in Table 3 . The average percent recoveries ranged from 98.20 to $101.27 \%$ indicating good accuracy of the methods.

The specificity of the methods was studied by evaluating the interference liabilities from the common tablet excipients, such as talc, lactose, starch, mannitol and magnesium stearate. No interference 
Table 2. Results of analytical parameters of the proposed methods

\begin{tabular}{|c|c|c|c|c|c|c|}
\hline \multirow[t]{2}{*}{ Parameters } & \multicolumn{2}{|c|}{ PRM } & \multicolumn{2}{|c|}{ NBV } & \multirow{2}{*}{$\begin{array}{c}\text { CRV } \\
\text { Spectrophotometric } \\
\text { method }\end{array}$} & \multirow{2}{*}{$\begin{array}{c}\text { ELT } \\
\text { Spectrophotometric } \\
\text { method }\end{array}$} \\
\hline & $\begin{array}{l}\text { Spectrophotometric } \\
\text { method }\end{array}$ & $\begin{array}{l}\text { Spectrofluorimetric } \\
\text { method }\end{array}$ & $\begin{array}{l}\text { Spectrophotometric } \\
\text { method }\end{array}$ & $\begin{array}{l}\text { Spectrofluorimetric } \\
\text { method }\end{array}$ & & \\
\hline Wavelength (nm) & $\lambda \max : 474$ & $\lambda$ ex $: 470, \lambda$ em $: 529$ & $\lambda \max : 484$ & $\lambda \mathrm{ex}: 473, \lambda \mathrm{em}: 530$ & $\lambda \max : 480$ & $\lambda \max : 480$ \\
\hline $\begin{array}{c}\text { Concentration range }{ }^{\mathrm{a}}(\mu \mathrm{g} \\
\left.\mathrm{mL}^{-1}\right)\end{array}$ & $10-60$ & $0.3-3.0$ & $2.0-40.0$ & $0.1-1.2$ & $7.0-60.0$ & $30-250$ \\
\hline \multicolumn{7}{|l|}{ Regression equation ${ }^{\mathrm{b}}$} \\
\hline Intercept $\pm \mathrm{SD}$ & $-0,0969 \pm 0.063$ & $8.0837 \pm 0.55$ & $0.0523 \pm 0.0007$ & $152.69 \pm 2.19$ & $0.0138 \pm 0.00027$ & $-0.1578 \pm 0.002383$ \\
\hline Slope \pm SD & $0,0906 \pm 0.096$ & $22.181 \pm 0.89$ & $0.0191 \pm 0.0002$ & $722.1 \pm 5.6$ & $0.0149 \pm 0.00110$ & $0.1009 \pm 0.004222$ \\
\hline Correlation coefficient $\left(\mathrm{r}^{2}\right)$ & 0.9997 & 0.9983 & 0.9994 & 0.9999 & 0.9997 & 0.9995 \\
\hline \multicolumn{7}{|l|}{ Precision } \\
\hline Intra-day ${ }^{\mathrm{c}}, \mathrm{RSD} \%$ & 0.55 & 0.85 & 0.91 & 0.68 & 0.98 & 0.98 \\
\hline Inter-day ${ }^{\mathrm{d}}, \mathrm{RSD} \%$ & 0.89 & 1.14 & 1.02 & 0.95 & 1.45 & 1.43 \\
\hline $\operatorname{LOD}\left(\mu \mathrm{g} \mathrm{ml}^{-1}\right)$ & 2.08 & 0.074 & 0.110 & 0.010 & 0.055 & 0.070 \\
\hline $\operatorname{LOQ}\left(\mu \mathrm{g} \mathrm{ml}^{-1}\right)$ & 6.95 & 0.247 & 0.367 & 0.0334 & 0.185 & 0.236 \\
\hline
\end{tabular}

${ }^{\mathrm{a}}$ Average of five determinations. ${ }^{\mathrm{b}} A=a+b C$ (where $C$ is the concentration of drug in $\mu \mathrm{g} \mathrm{mL}{ }^{-1}$ ). ${ }^{\mathrm{c}}$ Results of 5 different days. ${ }^{\mathrm{d}} \mathrm{n}=5 \mathrm{correspond}$ to replicate analysis for each level

Table 3. Results of recovery studies by standard addition method

\begin{tabular}{|c|c|c|c|c|c|c|}
\hline \multicolumn{2}{|c|}{ Methods } & \multirow{2}{*}{$\begin{array}{c}\begin{array}{c}\text { Amount taken } \\
\left(\mu \mathrm{g} \mathrm{mL}^{-1}\right)^{\mathrm{a}}\end{array} \\
30.0\end{array}$} & \multirow{2}{*}{$\begin{array}{c}\begin{array}{c}\text { Amount added } \\
\left(\mu \mathrm{g} \mathrm{mL}^{-1}\right)\end{array} \\
10.0\end{array}$} & \multirow{2}{*}{$\begin{array}{c}\left.\begin{array}{c}\text { Total amount found } \\
\left(\mu \mathrm{gL}^{\mathrm{b}}\right)(\text { Mean } \pm \text { S.D. } \\
\end{array}{ }^{\mathrm{c}}\right) \\
40.120 \pm 0.32\end{array}$} & \multirow{2}{*}{$\begin{array}{c}\text { Recovery }(\%) \\
101.20\end{array}$} & \multirow{2}{*}{$\begin{array}{c}\mathrm{RSD}(\%) \\
0.80\end{array}$} \\
\hline PRM & Spectrophotometric & & & & & \\
\hline & Method & & 20.0 & $49.980 \pm 0.55$ & 99.90 & 1.10 \\
\hline & & & 30.0 & $60.140 \pm 0.68$ & 100.47 & 1.13 \\
\hline & Spectrofluorimetric & 1.0 & 0.3 & $1.301 \pm 0.012$ & 100.33 & 0.92 \\
\hline & Method & & 1.0 & $2.013 \pm 0.025$ & 101.34 & 1.24 \\
\hline & & & 2.0 & $2.986 \pm 0.038$ & 99.30 & 1.27 \\
\hline \multirow[t]{6}{*}{ NBV } & Spectrophotometric & 5.0 & 2.0 & $6.99 \pm 0.050$ & 99.50 & 0.72 \\
\hline & Method & & 15.0 & $20.190 \pm 0.210$ & 101.27 & 1.04 \\
\hline & & & 35.0 & $40.150 \pm 0.265$ & 100.43 & 0.66 \\
\hline & Spectrofluorimetric & 0.70 & 0.10 & $0.799 \pm 0,004123$ & 99.99 & 0.52 \\
\hline & Method & & 0.30 & $1.00 \pm 0.005765$ & 100.14 & 0.58 \\
\hline & & & 0.50 & $1.20 \pm 0.007987$ & 100.22 & 0.67 \\
\hline \multirow[t]{3}{*}{ CRV } & Spectrophotometric & 5.0 & 2.0 & $7.01 \pm 0.054$ & 100.50 & 0.77 \\
\hline & Method & & 25.0 & $29.65 \pm 0.34$ & 98.60 & 1.15 \\
\hline & & & 55.0 & $59.01 \pm 0.67$ & 98.20 & 1.14 \\
\hline \multirow[t]{3}{*}{ ELT } & Spectrophotometric & 50 & 30 & $79.71 \pm 0.502$ & 99.03 & 0.63 \\
\hline & Method & & 100 & $149.79 \pm 0.839$ & 99.79 & 0.56 \\
\hline & & & 200 & $249.61 \pm 1.068$ & 99.81 & 0.43 \\
\hline
\end{tabular}

${ }^{\text {a Pexola }}{ }^{\circledR}$ tablet (1 mg) (for PRM), Nexivol ${ }^{\circledR}$ tablet (5 mg) (for NBV), Kinetra ${ }^{\circledR}$ tablet (25 mg) (for CRV), Relpax film coated tablet (for ELT). ${ }^{b}$ Five independent analyses. 'Standard deviation

was observed from these excipients.

The inter- and intra-day precision were examined by analysis of drugs $(n=5)$ for 7 consecutive days. The RSD values for intra-day precision and $\%$, and inter-day precision and $\%$, for spectrophotometric and spectrofluorimetric methods indicated good precision. The obtained results are summarized in Table 2.

Robustness was assessed by testing the susceptibility of measurements to deliberate variation of the analytical conditions. It was verified that slight variations in concentration of NBD-Cl $(0.45-0.55 \%$, $\mathrm{w} / \mathrm{v})$, temperature (optimum $\pm 2{ }^{\circ} \mathrm{C}$ ), and time (optimum $\pm 0.25 \mathrm{~min}$ ) did not have an adverse impact on the subject derivatization procedure. All precision studies yielded RSD values not more than $2 \%$. The most critical factor affecting the test results was determined to be the $\mathrm{pH}$ which was adjusted to be in the range of $8.5 \pm 0.2$ in order to generate the maximum response or $8.0 \pm 0.2$.

\section{Applications of the method}

The proposed methods were successfully applied to the analyses of marketed products $\left(\right.$ Pexola $^{\circledR}$ tablet, Nexivol ${ }^{\circledR}$ tablet, Kinetra ${ }^{\circledR}$ 
Table 4. Statistical evaluations of the results obtained by proposed and reference $(6,1)$ methods for the assay of drugs in pharmaceutical preparations $(n=5)$

\begin{tabular}{|c|c|c|c|c|c|c|c|c|c|c|}
\hline \multirow{2}{*}{$\begin{array}{l}\text { Statistical } \\
\text { value }\end{array}$} & \multicolumn{3}{|c|}{ PRM } & \multicolumn{3}{|c|}{ NBV } & \multicolumn{2}{|c|}{ CRV } & \multicolumn{2}{|c|}{ ELT } \\
\hline & $\begin{array}{l}\text { Spectro- } \\
\text { photometric } \\
\text { method }^{\mathrm{a}}\end{array}$ & $\begin{array}{l}\text { Spectro- } \\
\text { fluorimetric } \\
\text { method }^{\mathrm{a}}\end{array}$ & $\begin{array}{c}\text { Ref. } \\
\text { Method }^{7}\end{array}$ & $\begin{array}{l}\text { Spectro- } \\
\text { photometric } \\
\text { method }^{\mathrm{a}}\end{array}$ & $\begin{array}{l}\text { Spectro- } \\
\text { fluorimetric } \\
\text { method }^{\mathrm{a}}\end{array}$ & $\begin{array}{c}\text { Ref. } \\
\text { Method }^{11}\end{array}$ & $\begin{array}{c}\text { Spectro- } \\
\text { photometric } \\
\text { Method }^{\mathrm{a}}\end{array}$ & $\begin{array}{c}\text { Ref. } \\
\text { Method }^{16}\end{array}$ & $\begin{array}{c}\text { Spectro- } \\
\text { photometric } \\
\text { method }^{\mathrm{a}}\end{array}$ & $\begin{array}{c}\text { Ref. } \\
\text { Method }^{17}\end{array}$ \\
\hline Mean $^{\mathrm{b}}$ & 1.004 & 1.002 & 1.014 & 5.07 & 5.01 & 5.03 & 24.94 & 25.31 & 40.04 & 40.08 \\
\hline $\begin{array}{l}\text { Recovery } \\
(\%)\end{array}$ & 100.40 & 100.20 & 101.4 & 101.40 & 100.28 & 100.52 & 99.75 & 101.25 & 101.03 & 100.21 \\
\hline $\begin{array}{l}\text { RSD } \\
(\%)\end{array}$ & 1.34 & 1.64 & 1.49 & 1.32 & 1.22 & 1.11 & 0.25 & 1.48 & 0.92 & 1.09 \\
\hline $\begin{array}{l}\text { t-test of } \\
\text { significance }^{c}\end{array}$ & 1.13 & 1.10 & & 1.12 & 0.33 & & 0.29 & & 1.28 & \\
\hline $\begin{array}{l}\text { F-test of } \\
\text { significance }^{c}\end{array}$ & 1.28 & 0.85 & & 0.703 & 0.84 & & 2.37 & & 1.39 & \\
\hline
\end{tabular}

${ }^{\text {a Pexola }}{ }^{\circledR}$ tablet $\left(1 \mathrm{mg}\right.$ ) (for PRM), Nexivol ${ }^{\circledR}$ tablet $\left(5 \mathrm{mg}\right.$ ) (for NBV), Kinetra ${ }^{\circledR}$ tablet $\left(25 \mathrm{mg}\right.$ ) (for CRV), Relpax ${ }^{\circledR}$ film coated tablet ( $40 \mathrm{mg}$ ) (for ELT). ${ }^{\mathrm{b}} 5 \mathrm{independent}$ analyses. ${ }^{c} \mathrm{p}=0.05, \mathrm{t}=2.23, \mathrm{~F}=5.05$

tablet and Relpax ${ }^{\circledR}$ film coated tablet) and the results obtained are summarized in Table 4. Statistical analysis of the results obtained by the proposed method and reference HPLC methods ${ }^{6,11,17}$ for PRM, NBV and ELT, respectively and UV spectrophotometric method ${ }^{16}$ for CRV were performed using the Student's $t$-test and the variance ratio $F$-test. The calculated values were comparable with that of the theoretical test results indicating no significance difference between the compared methods regarding accuracy and precision.

\section{CONCLUSION}

New simple, sensitive and selective spectrophotometric and spectrofluorimetric methods, which comprise NBD-Cl as derivatization reagent, have been developed and validated for determination of PRM, NBV, CRV and ELT. The proposed methods were successfully applied for the subject drug substances and their respective drug products, and proven to be selective, highly sensitive, accurate, and precise. Therefore, the proposed methods are suitable for routine assay determination of PRM, NBV, CRV and ELT .

\section{SUPPLEMENTARY MATERIAL}

Available at http://quimicanova.sbq.org.br in PDF format, with free access.

\section{ACKNOWLEDGEMENT}

I would like to thank to the Research Fund of Istanbul University for supporting the subject scientific study (Project numbers: BYP1909 and BYP-3252).

\section{REFERENCES}

1. Hubble, J. P.; Novak, P.; Exp. Rev. Neurother. 2001, 1, 43.
2. McCormack, P. L.; Siddiqui, M. A. A.; CNS Drugs 2007, 21, 429.

3. The Merck Index; Budavari, S., ed.; $13^{\text {th }}$ ed., Merck \& Co., Inc.: Whitehouse Station, 2001, p. 1152.

4. Moen, M. D.; Wagstaff, A. J.; Drugs 2006, 66, 1389.

5. Abshangen, U.; J. Cardiovasc. Pharmacol. 1987, 10, 23.

6. Goadsby, P. J.; Ferrari, M. D.; Olesen, J.; Stovner, L. J.; Senard, J. M.; Jackson, N.C.; Poole, P. H.; Neurology 2000, 54, 156.

7. Srinubabu, G.; Jaganbabu, K.; Sudharani, B.; Venugopal, K.; Girizasankar, G.; Rao, J. V. L. N. S.; Chromatographia 2006, 64, 95.

8. Jancic, B.; Medenica, M.; Ivanovic, D.; Malenovic, A.; Acta Chim. Slov. 2007, 54, 49.

9. Shah, D. A.; Bhatt, K. K.; Mehta, R. S.; Baldania, S. L.; J. AOAC Int. 2008, 91, 1075.

10. Dhandapani, B.; Kumar, K. S.; Dharuman, J.; Geetha, K.; Asian J. Chem. 2008, 20, 1648.

11. Kachhadia, P. K.; Doshi, A. S.; Joshi, H. S.; J. AOAC Int. 2008, 91, 557.

12. Doshi, A. S.; Bhagwan, S. S.; Mehta, T. N.; Gupta, V. K.; Subaaiah, G.; J. AOAC Int. 2008, 91, 292.

13. Shah, D. A.; Bhatt, K. K.; Mehta, R. S.; Baldania, S. L.; Gandhi, T. R.; Ind. J. Pharm. Sci. 2008, 70, 591.

14. Reddy, T. S.; Devi, P. S.; J. Planar Chromatogr.-Mod. TLC 2007, 20, 149.

15. Cardoso, S. G.; Ieggli, C. V.; Pomblum, S. C.; Pharmazie 2007, 62, 34.

16. Ieggli, C. V.; Cardoso, S. G.; Belle, L. P.; J. AOAC Int. 2005, 88, 1299.

17. Sagirli, O.; Onal, A.; Sensoy, D.; Chromatographia 2008, 68, 269.

18. Pesez, M.; Batros, J.; Colorimetric and Fluorimetric Analysis of Organic Compounds and Drugs, Marcel Dekker: New York, 1974, p. 170.

19. Saleh, H. M.; El-Henawee, M. M.; Ragab, G. H.; El-Hay, S. S.; Spectrochim. Acta, Part A 2007, 67, 1284.

20. Olojo, R. O.; Xia, R. H.; Abramson, J.; J. Anal Biochem. 2005, 339, 338.

21. Önal, A.; Sagirli, O.; Spectrochim. Acta, Part A 2009, 72, 68.

22. Önal, A.; J. AOAC Int. 2006, 89, 972.

23. Önal, A.; Sagirli, O.; Cetin, S. M.; Toker, S.; Chromatographia 2007, 66,103.

24. Job, P.; Anal. Chem. 1928, 9, 113. 
SPECTROPHOTOMETRIC AND SPECTROFLUORIMETRIC DETERMINATION OF SOME DRUGS CONTAINING SECONDARY AMINO GROUP IN BULK DRUG AND DOSAGE FORMS VIA DERIVATIZATION WITH 7-CHLORO-4-NITROBENZOFURAZON

Armağan Önal

Department of Analytical Chemistry, Faculty of Pharmacy, Istanbul University, 34116, Beyazit, Istanbul - Turkey

Sensitive and selective spectrophotometric and spectrofluorimetric methods have been developed for determination of some drugs such as Pramipexole, Nebivolol, Carvedilol, and Eletriptan, which commonly contain secondary amino group using 7-Chloro-4-nitrobenzofurazon.<smiles>O=[N+]([O-])c1ccc(Cl)c2nonc12</smiles>

NBD-Cl<smiles>[R]N[NH3+]</smiles>

Drug<smiles></smiles>

Drug-NBD derivative 